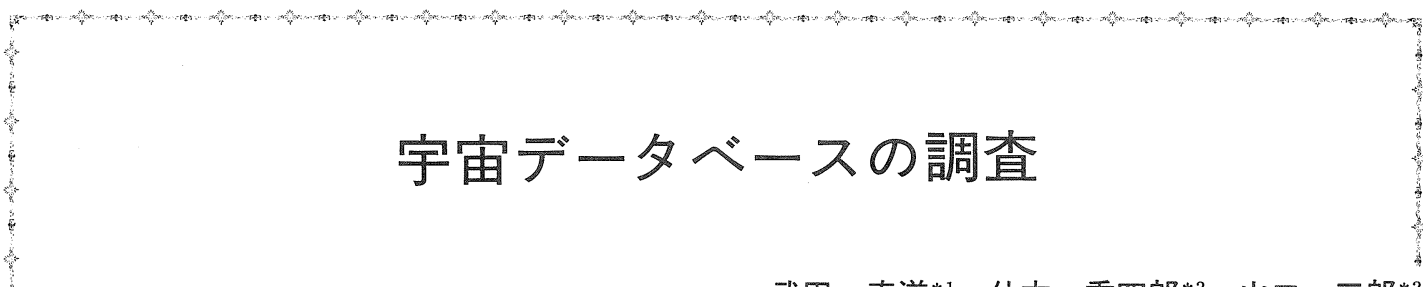

武田 直道 ${ }^{* 1}$, 仲本 秀四郎*2, 山口 三郎*2

\title{
Surveys for database of space experiments
}

TAKEDA Naomichi, NAKAMOTO Hideshiro, YAMAGUCHI Saburo

［著者抄録］宇宙環境利用データベースの設計資料とするため，情報源や現行サービス中の 関連データベースおよび対象となる情報について調査を行った。引用解析によれば，情報源は 集中し，寿命も比較的短い。市販データベースの調査では Aerospace Database が文献情報の ほとんどを網羅し, 日本語データベースではJICST ファイルがよく拾っていることを明らかに した。対象情報の解析によって，規模・成長数を推定し，計画データベースはファイル数が多 くサイズの小さいものとなり,データの容量より構造に焦点が絞られると結論した。データベ 一スの設計に当たっての情報調査の手法を紹介したもので, このほかアンケートによって利用 者の意識および要求の傾向が把握され，システムの規模，機能を想定することができる。

[著者付与キーワード］＼cjkstart宇宙環境利用, データベース, 設計, 情報源,引用解析, Aerospace Database, JICST ファイル,データ構造

[Author Abstract] For obtaining the basic material to design database of space experiments, Japan Space Utilization Promotion Center has investigated the information sources, the current database services and requirements of users in space science. According to the citation analysis the existing information sources are centralized, and their lifetime is consideraly short. The survey on commercial databases show that Aerospace Database covers almost all of the document information, and JICST File as Japanese-text database has relatively wide coverage. The scope and growth of the conventional database services were estimated. It is concluded that the possible future database will not grow to large scale but have multi-files. Also an attention should be paid to complex data structure instead of data volumes. The report is intended to introduce survey methods for database building.

[Keywords by Author] database, space experiments, information sources, references scattering, lifeness, citation analysis, data structure, database design

* 1 宇宙開発事業団（干 105 港区浜松町 2-4-1） Tel。03(436) 1779

* 2 宇宙環境利用推進センター（广 162 新宿区西早稲田 2-21-16） Tel。03(5273) 2441

* 1 National Space Development Agency of Japan (4-2, Hamamatsucho 2-chome, Minato-ku, 105)

* 2 Japan Space Utilization Promotion Center (21-26, Nishi-waseda 2-chome, Shinjuku-ku, 162) 


\section{1.はじめに}

データベースの設計に当たっては，対象とする 情報の内容を把握することはもちろん，規模・挙 動を定量的に把握することが大きな課題である。 すなわち，データベースが対象とする情報の数と 大きさ・成長性は，設計での基礎的なデー夕とし て，重要な要素となっている。通常の電算機シス テムでは，記憶装置の容量が大きく，検索処理の 技術水準が高いから，高速大容量にしておきさ之 すれば支障がなく、設計デー夕が十分でないまま， ハードウエアの設計にかかることもある。しかし， 大力設計では，これらの值が仕事量，必要人員， 予算の積算に欠かせない重要なデータで，特に， 入力作業は専門的マンパワーを極度に必要とする 領域であるので，人件費が上昇しつつある状勢で は，確実に推算しておく必要がある。

本調査は,このような認識に基づき, 宇宙開発 事業団が検討を進めている宇宙環境利用のための 宇宙実験データベースを封象に，その概念の決定 に必要な基礎情報を得ることを目的に実施したも のであり，対象とする情報の特性調查および需要 調查を主眼とした。

この報告では，その調査の一部を紹介し，デー タベース設計における調査手法への参考に供する ことを期待した。

この調査は大別して，(1)現行データベースの調 査，(2)対象情報の調査，(3)ユーザの調査，の三つ のアプローチからなっている。

主たる目的が(2)の把握であり，情報の選択，出 力の内容を決好のが(3)であるとすれば，(1)は作

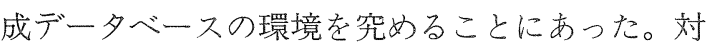
象の大部分が未発生の情報であるため，(2)は実験 計画に基づくとして，まだ発生していない情報の 量・流通の様子は(1)からの類推による手段しかな い。ここでは，(1)と(2)について紹介し，(3)は他の 機会に譲ることとしたい。

調査方法としては, 引用統計と, 市販データべ 一スへの検索を利用し，それぞれに得られたデー 夕を比較検討するとともに, サービス状況も調べ,
勘案して，解析することにした。すなわち，引用 統計によって，発行誌の重要性を判定することと し，まず，宇宙関係で最も情報数の多いとみられ る“Astrophysical Journal”の引用を調べ，その Bradford 曲線を描いて，core journals を定奴。 さらにその core journals の引用を調べ，同様に Bradford曲線を描いて，それぞれの core journalsを定め，このことから，この分野で重要な役 割を果たしている情報源が明らかになるので，デ 一タベース作成および情報サービスの封象となる スキャンニング誌りストを作成することができ た。

また，1984 年と 85 年に発表された論文中， $\lceil$ microgravity」の語を標題中に含む論文を計数 し，各誌ごとに数を当たって，微小重力の論文数 を算出した。

さらに, JOIS 抢よび各市販データベースにつ いて, microgravity 関連語をキーワードにして， 最近数年の各データベースでの大力数を調べ，比 較検討の結果, 宇宙開発関係の情報の特徵を把握 した。

\section{2. 引用解析}

\section{1 情報源の種類}

引用情報源のリストを眺めれば，その大部分が 雑誌論文であることは一目瞭然である (衰 1$)$ 。雑 誌論文の引用が雑誌論文であるのは当然の結果と も言之るが，多くの科学技術でも同様な特性を示 し，全体に占める大きさが分野ごとに異なってい るに過ざない。引用源がわかっている部分だけを 計数しても，シンポジウム，非刊行物・私信，プ リプリントは極めて少ない数である。

\section{2 分布特性}

(1) 各誌の引用データ

Astrophysical Journal, Astronomy and Astrophysics, Astronomical Journal, Astrophys. Space Science, Journal of Spacecraft and Rockets, Acta Astronauticaの各誌の論文が引 


\section{表 1 情報源の種類}

1) Astrophysical J.

$\begin{array}{llll}\text { 会議録 } & 2.28 \% & \text { 私信 } & 1.24 \% \\ \text { 非刊行物 } & 1.35 \% & \text { プリプリント } & 0.95 \%\end{array}$

2) Astronomy and Astrophysics

$\begin{array}{llll}\text { 会議録 } & 2.26 \% & \text { 私信 } & 0.83 \% \\ \text { 非刊行物 } & 0.92 \% & \text { プリプリント } & 0.74 \%\end{array}$

3) Astronomical J.

$\begin{array}{llll}\text { 会議録 } & 1.58 \% & \text { 私信 } & 1.15 \% \\ \text { 非刊行物 } & 0.92 \% & \text { プリプリント } & 1.10 \%\end{array}$

用した雑誌を統計したところ,自己引用を除くと， ほぼ一致した傾向を示した。

各リストにおけるランクをみると，各誌の貢献 度は安定しているといって差支えない。このこと は，情報収集にあたっての情報源選定に勇気を与 えるものである。限られた予算で情報の購入にあ たっている資料担当者に，効果／コストの根拠を 確実にする便宜がある。

(2) Bradford 曲線

各引用デー夕によって得られた Bradford曲線 を，図 1 に示す。従来の引用解析で得られた傾向 からいうと,この曲線群は非常に異様である。通 常の Bradford 曲線が示す core 部分のたるみが なく，第 1 位の情報源からほとんど直線性をもっ ている。Astronomy and Astrophysicsのごとき は，逆特性を示しており，集中した情報源がこの 分野の特性であること, 突出した core 情報源とい うべき雑誌のないことを示している。10 誌ほどで 貢献情報量の 50 〜 $70 \%$ を供給していること, 利用 のほぼ $90 \%$ の情報を 100 誌程度で供給している ことから, 非常に集約的な収集戦略が可能であり, 市販情報の収集を重点的に行いうると結論でき る。

（3）周辺情報

Astrophysical Journal 1984 が，43,779 件の引
用について，2,441の情報源を持っていることは， 多くの情報源を引用していて，裾野が広いという ことになる。すなおち，全引用数の $10 \%$ 以下を， 2,300にのぼる引用の低い情報源でカバーしてお り，集中性と矛盾したような特性である。いうな れば，非常にゆるい裾野と高く狭い頂上部分とい う形容になり，巨大科学の特徵ともいえる関係分 野の広さが, 宇宙科学でも呈示されているわけで ある。つまり，幅広い分野の情報を参照している が, majority が必要としている重要情報は極めて 少ない情報源に集中している。実際的にいえば， このdroopの部分は費用の割に貢献の少ない部 分であり, 経済性からいって，他のデータベース の利用に頼るべき情報源ということができる。

\section{3 情報の寿命}

代表的情報源である主要雑誌の半減期を表 2 に 示す。情報源の寿命は, 情報源に掲載されている 論文の寿命の平均で，どのくらいの古い論文を引 用しているかを示し, 逆にこの大小は, 古い情報 の評価基準を示すことにもなる。

表 2 にみように, $1.5 \sim 4$ 年位の值を示してお $\eta, 10$ 20 年の半減期を持つ他の雑誌に比べて, 極めて短い。これはこの分野の進歩が非常に早い ことを意味しており，情報が急速に古くなってい 


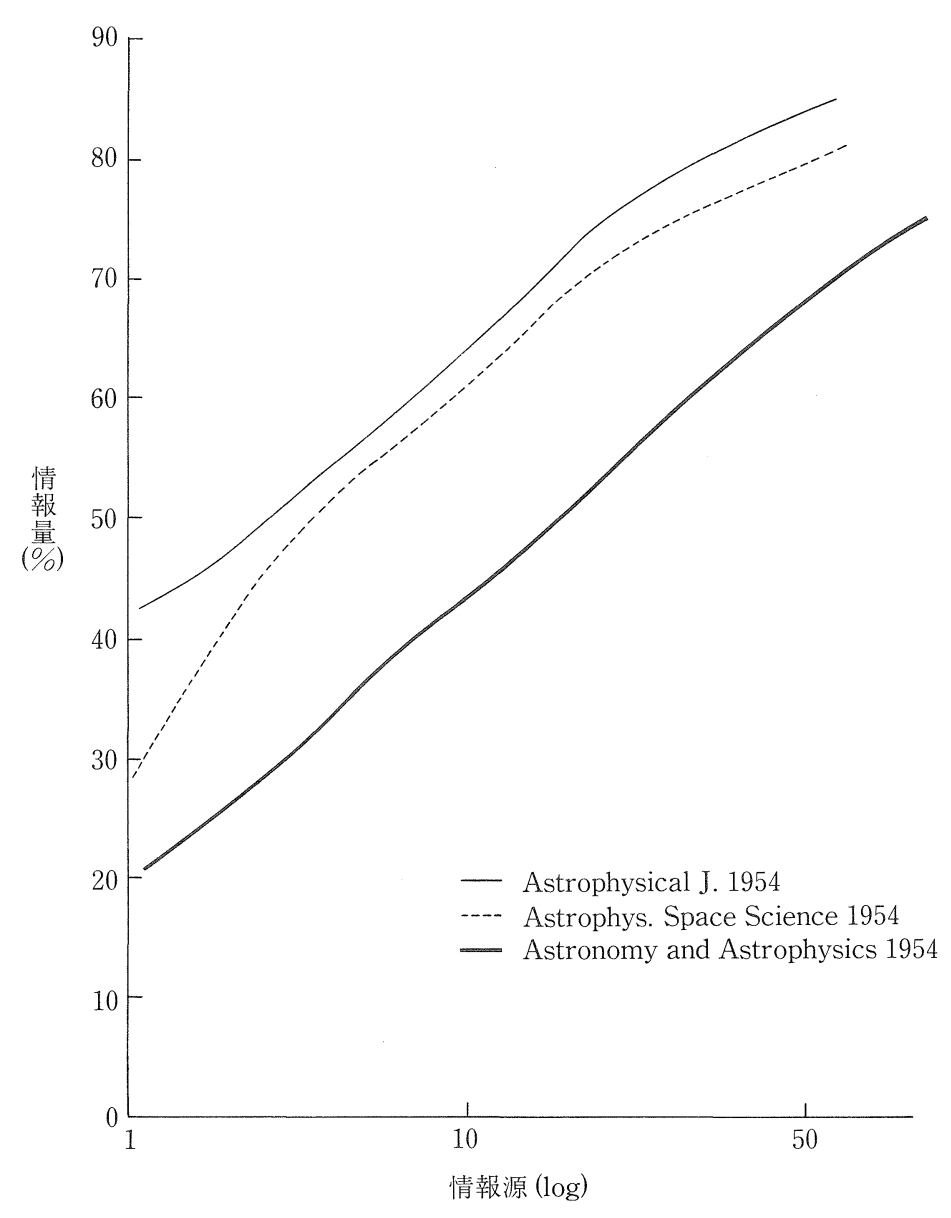

図 1

表 2 情報の寿命

\begin{tabular}{|ll|}
\hline & \\
Astrophysical Journal & 4.23 年 \\
Monthly Notice of the Royal Astronomical Soc. & 2.56 \\
Astronomy and Astrophysics, & 1.93 \\
Astrophysical J. Supplement Series & 3.66 \\
Astronomical Journal & 2.20 \\
IAU symp. & 1.46 \\
\hline
\end{tabular}


く原子力分野と同様の特性を示している。

データベースの運用からいうと，常時アクセス するワーキングファイルの遡及年数をそう大きく とる必要はなく，古い情報はバッチ処理するとし て，その境界の年数を想定しうる。

\section{3. 微小重力関係論文の調査}

範囲を狭め，関心の宇宙実験の特徵である微小 重力関係論文の調査を行った。現在利用されてい るS.C.I.およびIAA，STARの各文献ファイルに ついて，結果をまとめると次のとおりである。

(1) S.C.I.において，表題中に microgravity と いう語をもつ論文の著者を抽出し，その索引によ ク調べたところ，Science Citation Index が収録 している 625,432 件の文献中，表題に microgravityという語を持つ文献は，1984年に26， 1985 年に 54 で合計 80 ，掲載誌は 32 である。S.C. I.の収録誌には宇宙実験関係が少なく，科学技術 の中で地歩を占める量になっていない。

(2) IAA (International Aerospace Abstracts) ¿STAR (NASA, Scientific and Technical Aerospace Reports) の而文献ファイルからでき ている Aerospace Database では，収録対象誌は 858 誌で，ロシア文献をよく拾っている。

(3) STAR がレポート，特許，学位論文を含ん でいるに対し，IAA は定期刊行物，図書，会議録， 翻訳物などを収録している。S.C.I.で行った範囲を 広げ，主題として，微小重力または無重力を扱っ ている文献を抽出したところ，1984 年で 111 件， IAA が主題として微小重力または無重力を扱っ ている文献は 1984 年に 107 で，うち，36 件が会議 録，71 件が雑誌文献である。

(4) microgravity applications, reduced gravity, weightlessness simulation の四つのキーワード で検索し，概数を求めた。1977〜1986 (10 年間) にわたるIAAの微小重力関係文献は年間67〜 152, STAR は 67〜241，計 134～368であり，総 計は 1,074(IAA)，1,158(STAR)で，結局 2,232 となった。レポートが約 $50 \%$ を占めている。
Aerospace Database で2,111 件とした Battelle Columbus 研究所の調査 (昭和 61 年度) とも符合 した結果になっている。

\section{4. データベース収録性調查}

次いで，現在，日本で利用可能なデータベース について，その収録性を調べてみた。このデータ ベースシステムが指向している宇宙実験に関し て，現行のデータベースサービスに供されている 文献データベースが，どの程度収録しているかは， ファクトデータベースを作成するにしても，非常 に関心のあるところである。

\section{1 JICST データベースの収録性}

（1）キーワード「無重量」を持つ文献数

「無重量」で検索したところ表 3の結果となっ た。

年率でみると極めて高い成長率を示している。 これらの数は，その年の国際会議の開催などで大 きく変動するが，大筋はこのくらいとみて差支え ない。最後の期間は，時間おくれなどで，未入力 の分があるから参考までに眺めれば結構である。

（2）キーワード「宇宙環境」を持つ文献数 同じ期間のファイルでキーワード「宇宙環境」 でサーチすると 820 件となる。内容を詳しく検討 したうえで評価しなければならないが,数の上で, JICSTはよく拾っていると言えるであろう。

(3) キーワード「材料試験」を持つ文献数 キーワード「材料試験」をもつ文献は 25,101 件 ありそのうち,

「無重量」を併せ持つ文献 125 件

「宇宙環境」を併せ持つ文献 183 件

「無重量」「宇宙環境」を併せ持つ文献 120 件 「無重量」とインデクシングされた文献の大部分 が「宇宙環境」を共にしており，しかし，その逆 は必ずしもそうではない結果となって，概念の包 括関係を示している。「宇宙環境*材料試験」の「計 画」にかかわるもの 5 件である。

「培養」に関する文献は JOISファイルの同期間 
に 11,403 件収められているが，そのうち，「宇宙 環境」を併せ持つ文献は 2 件と，極めて少ない。 また，「航空宇宙医学」文献 127 件のうち，「宇宙 環境」を併せ持つ文献は 31 件であった。このほか, キーワード「宇宙通信」，「バイオテクノロジー」, 「宇宙ステーション」などで収録数も調べ，検討を 加えた。

\section{2 他のデータベースの収録性}

DIALOG が提供している各データベースにつ いて過去 10 年分の調査を試みた(表 4)。対象ファ イルは，BIOSIS (生命科学，500 万件，1969～), CA SEARCH (化学全般, 736 万件，1967～), NTIS (科学技術全般, 116 万件，1964～), COMPENDEX (工学全般，148 万件，1970～),
INSPEC（物理学・電気工学・電子工学・コンピュ 一夕, 284 万件, 1969 ), METADEX (金属・治 金・合金，621 万件，1966～）である。

調查式は，(MICRO OR LOW OR ZERO OR REDUCED) (2N) GRAVIT? OR WEIGHT-

\section{LESS}

LOW GRAVITY といった異概念が混大する などのノイズがあったが，おおむね概況をつかみ 得たと思われる。検索結果をみると，表 4 のとお クで，やはりINSPECがよく収録していると言 えるし，NTIS は地の利が良いのであろう。 METADEX の少ないのはこれからの状況を示し ているともいえる。

各データベースには，収録にかなり重複がある とみられるから，合計を文献量とみなすことはで

表 3 JICSTファイル「無重量」文献推移

\begin{tabular}{|cccc|}
\hline 期間 & 総件数 & 「無重量」 & 年率 \\
1975 年 4 月 1981 年 3 月 $(2,196,423$ 件 $)$ & 276 件 & $46 /$ 年 \\
1981 年 4 月 1984 年 3 月 $(1,331,292$ 件 $)$ & 261 件 & $87 /$ 年 \\
1984 年 4 月 1987 年 5 月 $(1,574,585$ 件 $)$ & 534 件 & $170 /$ 年 \\
1987 年 6 月 $~ 1988$ 年 1 月 & 195 件 & $334 /$ 年 \\
& & \\
& & & \\
\end{tabular}

表 4 市販データベース検索結果

\begin{tabular}{|lrr|}
\hline & & \\
BIOSIS & $7977 \sim 1986$ 件 & $1967 \sim 1976$ \\
CA SEARCH & 961 件 & 341 件 \\
NTIS & 850 件 & \\
COMPENDEX & 635 件 & 1003 件 \\
INSPEC & 1227 件 & 253 件 \\
METADEX & 222 件 & 243 件 \\
& & 45 件 \\
\hline
\end{tabular}


きない。合計 4,656 件から 3,500 件程度とみて, 他の調査とも合っている。この 10 年の推移を調べ たところ，JOIS と同様，年ごとに変動して，単調 な傾向を示していなかった。

\section{5. 対象情報の解析}

さらに，情報源の挙動や収録の状況など情報分 野での解析手法だけでなく，データベースが対象 とする情報量の推定作業を行った。実験計画から の計算，生産される報告での情報量の試算がその 内容である。

\section{1 実験計画および実験結果}

(1)落下塔・航空機・小型ロケット等による予備 実験計画と，(2)長期間の宇宙滞在による宇宙実験 計画とが対象であり，実験手段の違いはあるが， データベースとしては同じ扱いをして差支えない ものとみられる。この実験結果である，(3)予備実 験結果, (4)宇宙実験結果も, 計画と同じく考えら れるが，情報源がそしいので収集に困難を覚える ものと予想されている。

第 1 次材料実験計画 (FMPT) における材料系。 ライフ系を比較すると，ライフ系は材料系の 2 倍 以上の情報量となっており，1件あたりの情報量 は，文字・数值で $35 \mathrm{~Kb}$ ，イメージで 7 枚が得られ る。宇宙実験結果・予備実験結果については，小 型ロケットによる実験結果を調査対象とし, 実験 計画情報に結果解析にかかる情報量を加之て，情 報量は 1 件当たり，文字・数值で $66 \mathrm{~Kb}$ ，イメージ で 39 枚と推定された。

過去の実績は総数 347 件と見積もられ，スペー スシャトルによる今後のスペースラブ 2,3 での 実験件数は, 平均 70 件 / 1 フライトと推定するの が妥当である。また,シャトルに設置した MPESS (Mission Peculiar Equipment Support Structure）での宇宙材料実験は 4 件／1フライトとみ られる。小型ロケットは実績からみて 8 件 $/ 17$ ライトとみられる。 かくて，今後の実験計画については，フライト
計画に上記 1 フライト当たりの件数を乗じ，1993 年までの累計として，

文字.数值 $(\mathrm{Kb}): 21,700$ イメージ(枚) : 4,196 が得られた。

また，実験結果については，フライト 2 年後に 得られると仮定して，95 年までの累計

文字・数値 $(\mathrm{Kb}): 63,822$ イメージ(枚) : 37,713 という数字である。

\section{2 試料情報}

(1)〜(4)に供された(5)実験試料情報は，記述が極 端に少なく，1件当たり $5 \mathrm{~Kb} ， 2$ 枚とみなされ る。スペースラブ1 フライトあたりの実験 70 件す べてに試料情報を含むとみるのは見積過多かも知 れないが，安全側にみておくと，93 年までの累計 で,

文字・数值 $(\mathrm{Kb}): 4,545$ イメージ (枚) : 1,818 が得られた。

\section{5。3 装置仕栐情報}

(6)装置仕様の情報源としては, NASA 資料, NASDA 委託業務報告書が予定される外対象は 限られており,利用に耐えるレベルまで内容を整 えるには,かなりの努力が必要とされた。NASA MSFC (Microgravity Science and Application -Apparatus and Facilities) 冊子, NASA 冊子改 訂原稿，NASDA 冊子 1985 等から代表的装置の 情報量として，1装置当たり，

文字・数值：7( $\mathrm{Kb})$ イメージ：5 (枚)

のように推定された。

既開発装置として(a)小型ロケットおよびスペー スシャトル用がそれぞれ 129 個，(b)スペースシャ トル，宇宙ステーション用として計画中開発中の 装置が 202 個とみて，

文字. 数值 $7 \mathrm{~Kb} \times(129 \times 2+202)=3,220 \mathrm{~Kb}$ イメージ 5 枚 $\times(129 \times 2+202)=2,300$ 枚 となった。

\section{4 材料情報}

実験装置等に使用可能な(7)材料情報について 
は, 上記のような推定が妥当かどうかの議論がな された。すなわち，宇宙開発における材料の主眼 は，清浄度，おくれ破壞の恐れのないもの，耐応 力腐食等の特性のほか, (a) Outgas 特性, (b) Flamability 特性, (c)耐放射線性, (d)耐原子酸素等 の特性に重点が置かれるものとみられるが，研究 開発に重要な背景となる全般の材料情報を意識す れば，非常に大きな数となり，対象情報の解析か ら，積算するわけにはいかない。

通常，作成されている材料データベースから言 えば，この情報量の見積は別途考慮するのが妥当 であろう。量が大きくなって，予算・人員の点で 踏み込む内容には困難が伴う。すなわち, 宇宙関 係資料からのみでは, 需要に応え切れないとみら れることから，他の分野・機関で進められている 材料データベースを勘案して計画するのが妥当と 考えられた。

\section{6. むす び}

調查はこのほか，利用者に対するアンケート調 查を行い，その需要を調べたが，その内容は他の 機会に紹介するとして，以上の調查で判明したこ と，その結果にもとづく示唆は多々ある。めぼし いところを拾っても，

(1) 宇宙関係主要雑誌に掲載された文献の引用統 計をとると，雑誌，レポート，図書以外の刊行物 (会議録，非刊行物，私信，プリプリントなど)は $5 \%$ 程度と低く，非市販刊行物をそれほど参照し てないことになるが，論文執筆のかぎられた傾向 とも考えられる。

（2）文献情報では, 雑誌 10 誌ほどで宇宙に関係す る重要な文献情報の 50〜70\%を供給し，100 誌で ほぼ $90 \%$ をガーしている。この結果は, 情報収 集に当たって, 情報源の選定に困難の少ないこと， 収集コストが低減できることを意味している。

（3）文献情報利用の半減期は $1.5 \sim 4$ 年の間にあ って, 比較的短い。原子力と同様, 文献情報の古 くなり方が早く, 文献以外の情報はもっと短い。
(4) Aerospace Database の収録誌は 858 誌で, ロシア文献をよく拾っている。文献情報について は, Aerospace Databaseの導入でほとんどの用 に立つことが示された。

(5) IAAにおける微小重力関係文献の1977〜 1986年の10年間にわたる推移は，年間67〜152で あり, STAR (NASA, Scientific and Technical Information Branch) は67〜241, 計134〜368, 総計1,074 (IAA)，1,158 (STAR) で，結局 2,232 となり，レポートが約 $50 \%$ を占めている。

(6) JICSTデータベースで，キーワード「無重量」 のインデクシングされている文献は 1984 年以降 729 件を数え, 日本語データベースとしては JICSTファイルが，この分野をよく拾っているこ とを認識した。

（7）関係する科学技術情報データベースの BIOSIS (ライフサイエンス), CA SEARCH (化 学), NTIS (科学技術), COMPENDEX (工学), INSPEC (物理・電気・電子・電算機), METADEX (金属)の過去 10 年分約 1,800 万件に対し, 対象 文献をサーチすると 3,500 4, 656 となって, もち ろん重複がありうるが, Battelle Columbusなど の值と照合して，だいたいに合っている。

（8）対象情報の調查からわかったことは，作成予 定のデータベースはファイルの数が多く, サイズ が大きくなることはなくて，データの容量よりデ 一夕構造に焦点が絞られるであろうということで ある。

これらの結果を踏まえて，対象情報ごとに，作 成するデータベースの内容・形式について多様な 選択を答申した。あるものは情報解析データベー スに，あるものは全文データベースに，また，フ ァクトデータベースや索引ファイルの作成を提案 し，適当する主題および情報をとりまとめた。い ずれも大きなファイルになることはないと見ら れ，新しいメディアと技術の応用によって，意欲 的なデータベースが期待されるが，慎重な進め方 とテストの実施を委員会から勧告されている。 